\title{
The Effect of Life Cycle on Dividend Policies of Manufacturing Companies Listed in Indonesia Stock Exchange
}

\author{
Anisa Aryani ${ }^{*}$, Dina Patrisia ${ }^{2}$ \\ 1, 2 Universitas Negeri Padang, Padang, Indonesia \\ *Corresponding auhthor. Email: blancgie@gmail.com
}

\begin{abstract}
The purpose of this study is to assess the impact of the effect of life cycle on dividend policy of the Indonesian Stock Exchange. The population of this study are all manufacturing companies listed in Indonesia Stock Exchange during period 2014 to 2018 uses secondary data. The sampling method used is purposive sampling. The number of samples used in this analysis are 305 samples (61 companies with 5 years of research). The data analysis technique used is a multiple linear regression analysis with using SPSS 16 program. The results showed that the life-cycle variable had a positive and significant effect on dividend policy as calculated by the use of Retained Earnings to Total Equity (RE/TE), both using control variables or without using control variables.
\end{abstract}

Keywords: Dividend Policy, Life Cycle, Control Variable.

\section{INTRODUCTION}

The company has a goals to increase its shareholders capital via investment decisions and dividend policies, managers will aim to make this happen. Dividend policy is a decision whether the income received by the company will be distributed or paid to shareholders as dividends or will be retained or held in the form of retained earnings for future investment funding [1].

The dividend policy is calculated in this research by using Dividend Payout Ratio (DPR). According to [1], the dividend payout ratio is the percentage of profit to be paid in the form of dividends or the ratio between the profit to be paid in dividends and the total profit that will be paid available to shareholders.

The characteristics of different companies and the factors that determine the company in paying dividends are interesting to study. The company's life cycle is one of the variables that is thought to influence dividend policy. A company's life cycle is the growth of the company through predicted stages.

Companies with low RE/TE growth need a large source of funding to be able to finance their company activities. At this stage, the company tends to hold its profits to finance company activities, and reduce dividend payments. This is different from companies that have reached the maturity stage with high RETE and high accumulated profits tend to share the profits earned in the form of dividends [2].

This study uses control variables, size, cash/assets, profitability, and leverage. The purpose of including the variable size (size) company, cash/assets, profitability, and leverage as control variables is to control, so that the relationship that occurs in the dependent variable is purely influenced by the independent variable, not by other factors.

Previous research conducted by [3] examined reputation building and life cycle models of dividends in American companies. The results showed that separate and supportive classification approaches can provide almost the same results by emphasizing on the life cycle model of dividends. The increase in dividends on the life cycle peaks at the mature stage before fall into the shaky/decline stage. Dividends that varying at this stage of the life cycle are high and economically significant, particularly during the transition from growth to maturity. Research on dividend policy was previously conducted by [4] show that the life cycle has a different effect and positive on payment Policy dividend. The 
results of his research are in line with [5] in Egypt, which, based on this research, provides evidence for the presence of a life cycle theory against dividends in Egypt.

[6] analyzed the presence of evidence of the ability of cash flow-based life cycle proxies, established by [7], to explain the tendency of companies to pay dividends, that can be substantially increased.

Researchers are interested in using the research objective of the IDX-listed manufacturing companies for the period 2014-2018. Based on previous study which was conducted outside Indonesia, the researchers were interested in examining the effect of the life cycle on dividend policy in companies in the manufacturing companies.

\section{THEORETICAL BASIS}

\subsection{Life-Cycle}

The life cycle notes that a company has different risk characteristics at all points of its life cycle. They divide the company's life cycle into four stages: start-up, growth, maturity, and decline. This theory notes that mature companies would have smaller investment opportunities, which resulting in a lower level of investment, growth, and risk. Reduced investment will result in surplus cash that can be distributed to investors in the form of dividends.

According to [8] the company's life cycle model can be divided into five stages including:

a. Establishment Stage (Start-up). This stage is the initial stage in the company's life cycle. A new company at this stage has it capital requirements met by the owner (founder) plus loan funds from the bank.

b. Expansion Stage. At this stage the company has been able to position itself in the market and have costumes. The need for external funds at this stage is very high because the cash flow is relatively small. The initial choice usually comes from private or individual funds (private equity) and venture capital. It is not uncommon for companies to make decision to become public company.

c. Growth Stage. The stage when a company undergoes a transition to become a public company, so that choice of funding sources becomes more open. In general, a general trading company at this stage will be able to look at equity issues in the form of common stock, guarantees and other equity options as well. d. Mature Stage. Companies that enter this stage will experienced a rapid increase in profit and cash flow that reflects past investments. The need for external funds at this stage begins to decline, because the company has been able to meet the needs of funds from within, internal funds will be more attractive to be used as an alternative funding.

e. Decline Stage. Final stage in the company's life cycle. Companies that have entered this stage will experience a steady decline in revenue and profit as a consequences of the emergencies of new competitors that start to take over the market. The need for the external funds will decrease drastically because new projects or investment also decline and the amount of internal funds available in the company is very large.

\subsection{Dividend Policy}

According to [9], there are several forms of cash dividends or cash dividends given by companies to shareholders. The form of policy is:

a. Stable Dividend Distribution Policy. Dividends will be given regularly per sheet for a certain period of time even though the profits earned by the company are fluctuating. This stable dividend is sustained for several years, and if the profit obtained increases and the growth is steady and stable, then the dividend will also be increased and then maintained for several years.

b. Improved Dividend Policy. With this policy, the company will pay dividends to shareholders in an amount that always increases with stable growth.

c. Dividend Policy with Constant Ratio. This policy provides dividends, the amount of which follows the amount of profit earned by the company. The greater the profit obtained, the greater the dividends paid and vice versa if the small dividends paid are also small.

d. Gift Policy. The company determines the amount of dividend payments per sheet that is distributed small, then adds and extra dividend if the profit reaches a certain amount.

\subsection{Control Variables}

a. Size. The size of an organization is the size of a business. On the basis of its composition, the size of the organization can be categorized into large and small companies. In this study, the company is calculated on the basis on the natural $\log$ (In) value of total assets [10]. 
b. Cash / Assets. Used to illustrate the proportion of cash to total assets owned by the company.

c. Profitability. Profitability is the return on total assets (ROA) calculated by comparing net income available to common stockholders with total assets [11].

d. Leverage. Leverage is a ratio that measures how much the obligations support the company and shows its long term ability to pay and illustrates the level of interest expense and corporate debt expenses that arise because the company uses funds from external parties.

\section{CONCEPTUAL FRAMEWORK}

To provide a clear picture of the flow of this research, the following form of the conceptual framework of this research is presented as seen in the following figure:

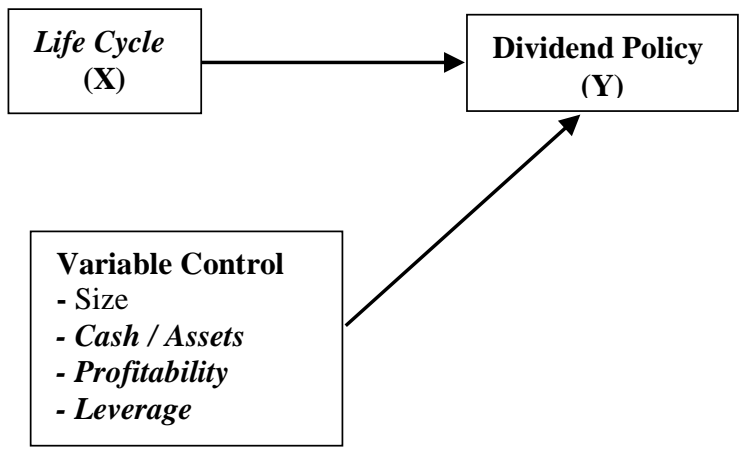

Based on theoretical studies and previous research hypothesis can be formulated:

H1: The life cycle affects the dividend policy in manufacturing companies listed on the IDX

\section{RESEARCH METHODS}

This study is a form of causal research that attempts to test hypotheses about the influence on other variables or more variables (independent variables). for the period 2014-2018, the population in this sample was as many as 174 firms, all manufacturing companies on the IDX. The sampling technique used was purposive sampling with sampling criteria, namely manufacturing companies listed in Indonesia Stock Exchange and companies that did not experience losses during the study period. From the purposive sampling criteria, it was found that 61 companies were multiplied by 5 years of observation. Thus, the total sample of this study is 305 samples data studied. This research uses multiple regression analysis.

Figure 1. Conceptual Framework

Table 1. Definition of Variable Operations

\begin{tabular}{|l|l|l|}
\hline \multicolumn{1}{|c|}{ Variable } & \multicolumn{1}{c|}{ Definition } & \multicolumn{1}{c|}{ Formula } \\
\hline $\begin{array}{l}\text { Dependent (Dividend } \\
\text { Policy) }\end{array}$ & Policy to pay profits to shareholders & DPR $\frac{\text { dividends per shave }}{\text { Earning per share }} \times 100 \%$ \\
\hline Independent (Life cycle) & The life stages of the company $=\frac{\text { REit }}{\text { TEit }}$ \\
\hline $\begin{array}{l}\text { Control Variables: } \\
\text {-Size } \\
\text {-Cash / Assets } \\
\text {-Profitability }\end{array}$ & $\begin{array}{l}\text { The size of the company } \\
\text {-Leverage } \\
\text { The company's ability to make a profit } \\
\text { To see how far the company is financed by bize } \\
\text { debt }\end{array}$ & $\begin{array}{l}\text { Return } \text { On } \text { Asset }=\frac{\text { Laba Setelah Pajak }}{\text { Total asset }} \\
\text { Total liabilities }\end{array}$ \\
\hline
\end{tabular}

\section{RESULTS AND DISCUSSION}

\subsection{Research result}

The research variable description refers to the lowest value, highest value, average, and standard deviation of the results. Tool for checking using Window SPSS 16. The descriptive results of the studies in this sample are as follow: 
Table 2

\begin{tabular}{|l|c|r|r|r|r|}
\hline \multicolumn{7}{|c|}{ Descriptive Statistics } \\
\hline & $\mathrm{N}$ & Min & Max & Mean & $\begin{array}{c}\text { Stan. } \\
\text { Deviation }\end{array}$ \\
\hline $\begin{array}{l}\text { Dividend } \\
\text { Policy }\end{array}$ & 305 & .00 & $\begin{array}{r}145 . \\
76\end{array}$ & $\begin{array}{r}27,46 \\
51\end{array}$ & 27,8085 \\
\hline Life Cycle & 305 & .00 & 2.49 & .5893 & .33224 \\
\hline $\begin{array}{l}\text { Company } \\
\text { Size }\end{array}$ & 305 & $\begin{array}{r}1337 \\
83.00\end{array}$ & $\begin{array}{r}3.45 \\
\mathrm{E} 8\end{array}$ & $\begin{array}{r}1,25 \mathrm{E} \\
+11\end{array}$ & $3,81 \mathrm{E}+12$ \\
\hline $\begin{array}{l}\text { Cash Per } \\
\text { Assets }\end{array}$ & 305 & .00 & 1.99 & .1256 & .16485 \\
\hline Profitability & 305 & .00 & .92 & .0925 & .09921 \\
\hline Leverage & 305 & .07 & 6.34 & .8530 & .80029 \\
\hline $\begin{array}{l}\text { Valid N } \\
\text { (listwise) }\end{array}$ & 305 & & & & \\
\hline
\end{tabular}

Based on Table 2, the lowest DPR score can be seen is $0 \%$ for WTON companies in 2016, ARNA companies in 2014 and 2015, and ISSP companies in 2015 and 2018, and so on.The highest value of the dividend policy is $145.76 \%$ in the Multi Bintang Indonesia (MLBI) company in 2016 which paid dividends exceeding its net profit, the average value was $27.46 \%$ the average manufacturing company distributes dividends of $27.46 \%$ of net income, the standard deviation of dividend policy amounted to $27.80 \%$. The lowest value of life cycle amounting to -0.0059 times or $-0.59 \%$ in the Indo Acidatama company (SRSN) in 2014 , the highest value of life cycle was 2.488 times or $248.8 \%$ in the Akasha Wira International (ADES) company in 2014 , the average life cycle is 0.589 times or $58.9 \%$, meaning that the average manufacturing company on the IDX has a net profit of $58.9 \%$ of total assets owned and the standard deviation of the life cycle is 0.332 times or $33.2 \%$. The lowest value of company size (size) amounting to $\mathrm{Rp} 1,180,397,436$ in the Lionmesh Prima (LMSH) company in 2015, the highest value of company size (size) was Rp1,965.8 21,694 at the Astra International (ASII) company in 2018, the average size value was $\mathrm{Rp} 1,474,375,939$ times the standard deviation of the size of Rp162,482,907. The lowest cash per asset value was 0.0008 times at the Wilmar Cahaya Indonesia (CEKA) company in 2018, the highest cash per asset value was 1.987 times or $198.7 \%$ at the Wijaya Karya Beton (WTON) company in 2016, the average cash value per asset is 0.1255 times or $12.55 \%$, the standard deviation of cash per asset is 0.1648 times or $16.48 \%$. The lowest profitability value was 0.00 times at the company (STAR) in 2018, the highest profitability value was 0.9209 times or $92.09 \%$ at the Merck Indonesia company (MERK) in 2018, the average profitability value was 0.0924 times or 9 , $24 \%$ with that meaning the average manufacturing company on the IDX has a net profit of $9.24 \%$ of total assets owned, the standard deviation of profitability is 0.0992 times or $9.92 \%$. And the lowest value of leverage is 0.0743 times or $7.43 \%$ in the Sido Muncul Herbal \& Pharmaceutical Industry (SIDO) company in 2014 , the highest leverage value is 6,340 times or $634 \%$ in the Indal Aluminum Industry (INAI) company in 2014. The average leverage is 0.8530 times or $85.30 \%$. The standard deviation of leverage is 0.8002 times or $80.02 \%$.

\section{MULTIPLE LINEAR REGRESSION ANALYSIS TEST RESULTS}

\subsection{Hypothesis Results}

Hypothesis test is used to determined whether or not there is a meaningful effect between the independent variable and the dependent variable partially. In testing this hypothesis, the researcher determines that this analysis is based on the significance value of 0.05 . If the significance of $\mathrm{t}<0.05$, it means that the independent variable partially affects the dependent variable. If the significance of $t>0.05$, it means that the independent variable partially has no influence on it in part.

Table 3. Test results

\begin{tabular}{|c|c|c|c|c|}
\hline & \multicolumn{2}{|c|}{$\begin{array}{l}\text { Model } 1 \\
\text { No Control } \\
\text { Variable }\end{array}$} & \multicolumn{2}{|c|}{$\begin{array}{l}\text { Model } 2 \\
\text { With Control } \\
\text { Variables }\end{array}$} \\
\hline & $B$ & Beta & $B$ & Beta \\
\hline (Constant) & $\begin{array}{l}4,955 \\
* \star * \\
(2.31)\end{array}$ & & $\begin{array}{l}-4,943 \\
\star \star \\
(2,423)\end{array}$ & \\
\hline Life Cycle & $\begin{array}{l}2,321 \\
\star \star \star \\
(2,423)\end{array}$ & .264 & $\begin{array}{l}1,151 \text { ** } \\
(.497)\end{array}$ & .131 \\
\hline $\begin{array}{l}\text { Company } \\
\text { Size }\end{array}$ & & & $\begin{array}{l}.532^{\star * *} \\
(.103)\end{array}$ & .275 \\
\hline $\begin{array}{l}\text { Cash Per } \\
\text { Assets }\end{array}$ & & & $\begin{array}{c}1,320 \\
(1,925)\end{array}$ & .036 \\
\hline Profitability & & & $\begin{array}{l}6,638 \\
\star \star \star \\
(1,760)\end{array}$ & .210 \\
\hline $\begin{array}{l}\text { Leverage } \\
\mathrm{F} \text { test } \\
\mathrm{R}^{2} \\
\mathrm{~N}\end{array}$ & $\begin{array}{l}22,647 \\
* * * \\
.066 \\
305\end{array}$ & & $\begin{array}{l}-281 \\
(.206) \\
14,684 \\
\star \star \star \\
184 \\
305\end{array}$ & -.072 \\
\hline
\end{tabular}

The numbers in parentheses are the standard error

*** Significant at $1 \%, * *$ at $5 \%, *$ at $10 \%$

Based on Table 3, the equation can be formed, namely:

$\mathrm{DPR}=-4,943+1,151 \mathrm{LC}+0,532 \mathrm{SIZE}+1,320 \mathrm{C} / \mathrm{A}+$ 6,638ROA - 0,281Lev + e

A constant value of $-4,943$ is negative, so if the Life cycle, Company Size, Cash per Assets, Profitability, and Leverage are zero, the dividend policy has decreased. The value of the Life cycle regression coefficient with 
the control variable on dividend policy is 1.151 which is positive, so each increase in Life cycle will increase the dividend policy. This is the same as without the control variable. The size regression coefficient value is 0.532 with a positive sign, so any increase in size will increase the dividend policy. This is the same as without the control variable. The cash per asset regression coefficient value is 1.320 with a positive sign, so any increase in cash per asset will increase the dividend policy. This is the same as without the control variable. The profitability regression coefficient value is 6.638 with a positive sign, so any increase in profitability will increase dividend policy. The leverage regression coefficient value is 0.281 with a negative sign, so any increase in leverage will reduce dividend policy.

Based on Table 3, it can be clarified that the life cycle using model 1 has a significance value of $0.000<0.05$, so the hypothesis is aproved with the conclusion that life cycle has a significant and positive effect on dividend policy. And in Table 3, the life cycle variable using model 2 has a significance value of 0.021 $<0.05$, so the hypothesis is accepted with the result that life cycle has a positive and significant effect on dividend policy. The control variable size has a significance value of $0.000<0.05$, so the hypothesis is accepted with the conclusion that size has a positive and significant effect on dividend policy. The control variable cash per asset has a significance value of $0.493>0.05$, so the hypothesis is rejected, with the conclusion that cash per asset has no positive effect on dividend policy.

The profitability control variable has a significance value of $0.000<0.05$, so the statement is accepted with the result that profitability has a positive and significant effect on dividend policy. The leverage control variable has a significance value of $0.174>0.05$, so the hypothesis is rejected with the conclusion that leverage has no positive effect on dividend policy.

In model 1 with no control variables, it can be explained that the adjusted $\mathrm{R}$ square value is 0.066 . The size of the effect of the life-cycle component on the DPR is $6.6 \%$, while the remaining $93.4 \%$ is affected by other factors outside this study model. In model 2, using control variables, it can be clarified that the adjusted $\mathrm{R}$ square value is 0.184 . The value of the life-cycle variable with the control variable on the DPR is $18.4 \%$, while the remaining $81.6 \%$ is influenced by other factors outside the research model.

\section{DISCUSSION}

The theory in this analysis demonstrates that life cycle, as calculated Dividend Payout Ratio (DPR) has significant effect on dividend policy. The results of the hypotheses testing without use of control variables suggested that the life cycle has a positive and significant effect on dividend policy with a significance value of $0.000<0.05$. With a significance value of 0.021 $<0.05$, the test findings using control variables offer the same conclusion. It can be said that an increase in the company's life cycle position will significantly increase the dividend distribution policy. So it can be stated that companies that are in a mature position do not need to invest anymore and are more likely to distribute or pay dividends. Meanwhile, companies that are still in the growth stage prefer to invest their profits.

The results of this study confirm previous studies undertaken by [3], [4], [12], [6], [5], [13], [7] which state that life cycle theory has a positive and significant effect on dividend policy.

\section{CONCLUSIONS}

\subsection{Conclusion}

Based on the researcher's hypothesis, it can be inferred that the life cycle variable influences the dividend policy as calculated through the use of the dividend payout ratio, either by using control variables or not using control variables in the IDX-listed manufacturing companies in 2014-2018.

\subsection{Suggestions}

Based on the conclusion, management or investors can implement some of the suggestions proposed. The suggestion is: The investors can see that at the stage of growth, the company has invested a very significant amount of investment to create and retain market share and the company continue to establish a reputation. Meanwhile, at the mature stage, the company is well known and has a good reputation. Sales growth has reached its maximum point, and the company's investment activity for fixed asset capital has begun to decrease and the company has been able to produce income from assets invested in the previous life cycle.

In this research, the researchers realize the shortcomings and limitations of the study, such as the researchers only uses the life cycle variable. This research was only carried out within a period of five years of research, and this research was limited to the manufacturing industry sector only. For further research, the researchers should add new variables such as cash flow that may affect dividend policy apart from the variables measured in this study. And, further, researchers can extend the research year and research on different industrial sectors so that they will produce different conclusions.

\section{REFERENCES}

[1] Sartono, "Sartono, R. Agus. 2001. Manajemen Keuangan Teori dan Aplikasi. Edisi 4. Yogyakarta: BPFE.," in Revolusi Industri 4.0: Desain Perkembangan Transaksi dan Sistem Akuntansi Keuangan, 2001. 
[2] W.-R. Murhadi, "Munich Personal RePEc Archive Study On Dividend Policy: Antecedent and Its Impact On Share Price," no. 25596, 2008.

[3] T. Flavin and T. O'Connor, "Reputation building and the lifecycle model of dividends," Pacific Basin Financ. J., vol. 46, no. April, pp. 177-190, 2017, doi: 10.1016/j.pacfin.2017.09.006.

[4] M. Hassani and F. Kazem Pour Dizaji, "Life cycle theory and dividend payout policy: Evidence from Tehran Stock Exchange,” Manag. Sci. Lett., vol. 3, pp. 2631-2634, 2013, doi: 10.5267/j.msl.2013.09.005.

[5] O. El-Ansary and T. Gomaa, "The Life Cycle Theory of Dividends: Evidence from Egypt," Int. Res. J. Financ. Econ., no. 97, pp. 72-80, 2012.

[6] D. Bhattacharya, C. W. Chang, and W. H. Li, "Stages of firm life cycle, transition, and dividend policy," Financ. Res. Lett., no. September 2018, pp. 1-12, 2019, doi: 10.1016/j.frl.2019.06.024.

[7] V. Dickinson, "Cash flow patterns as a proxy for firm life cycle," Account. Rev., vol. 86, no. 6, pp. 1969-1994, 2011, doi: 10.2308/accr-10130.

[8] L. Damodaran, "Human factors in the digital world enhancing life style - The challenge for emerging technologies," in International Journal of Human Computer Studies, 2001, doi: 10.1006/ijhc.2001.0490.

[9] Sutrisno, Financial Management Theory, Concepts and Applications. Econocia. Yogyakarta, 2012.

[10] K. Nuringsih, “ANALISIS PENGARUH KEPEMILIKAN MANAJERIAL, KEBIJAKAN UTANG, ROA DAN UKURAN PERUSAHAAN TERHADAP KEBIJAKAN DIVIDEN: STUDI 1995-1996," J. Akunt. dan Keuang. Indones., vol. 2, pp. 103-123, Jan. 2005, doi: 10.21002/jaki.2005.12.

[11] A. P. D Prawironegoro, Akuntansi Manajemen. Jakarta: Jakarta Penerbit Mitra Wacana Media, 2008.

[12] R. Faff, W. C. Kwok, E. J. Podolski, and G. Wong, "Do corporate policies follow a life-cycle?," J. Bank. Financ., vol. 69, no. April, pp. 95-107, 2016, doi: 10.1016/j.jbankfin.2016.04.009.

[13] F. Moshtagh, M. R. Abbaszadeh, H. Nowghabi, and M. J. Nooghabi, "A sian R esearch C onsortium The Effect of Company's Life Cycle on Dividend Policy of Listed Companies on the Tehran Stock Exchange." 